\title{
Ethics Codes Of The Hungarian Top 200 Companies
}

Krisztina Szegedi, PhD, Associate Prof.

Department of Business Enterprises, University of Miskolc, Hungary

Roland Szilágyi, PhD, Associate Prof.

Department of Business Statistics and Prognosis, University of Miskolc, Hungary

doi: 10.19044/esj.2016.v12n13p402 URL:http://dx.doi.org/10.19044/esj.2016.v12n13p402

\begin{abstract}
The aim of this current article is to summarize the statements regarding the code of ethics examined in the empirical research of the Hungarian TOP 200 corporate ethics institution system. This study was conducted by the Ethics and Transparency work team of the Hungarian Business Leaders Forum. The research indicates that in Hungary, similar to transitional economies, the codes of ethics are also undeveloped. The main purposes of introducing the code of ethics include providing guidelines for employees, declaring ethical commitment, and the development of company's culture. Based on the topics, emphasis is laid on protecting the interests of the companies. However, improving competitiveness and meeting the expectations of stakeholders plays an insignificant role. The practice of the code of ethics in the Hungarian large companies contradicts the global tendency that the codes are more and more comprehensive. Thus, they contain several objectives that define corporate responsibility, and they not only focus on the do's and don'ts of employees.
\end{abstract}

Keywords: business ethics, code of ethics, ethics management, compliance

\section{Introduction}

The codes of ethics provide the basis for the ethics management systems. First of all, it is worthwhile for the ethics management to establish commitment to the ethical operation of the company. It composes of ethical values, and norms which are considered to be important by the company. Corporations often include their values and norms in the written code of ethics. This is with the aim of providing employees and other stakeholders with explicit guidelines for proper behaviour (Brenner, 1992; Watson \& Weaver, 2003; Kaptein, 2009). 
It is effective particularly in a case of complex organizations. In such areas, due to the potential ethics problems, it is suggested based on the relevant law, sectorial regulations, and guidelines. Based on the survey of Garegnani et al. (2015), the quality of the code is significantly affected by the size of the companies and the criticality of the stakeholders. The written norms reduce the ethical risks of the corporations and their owners as well as the possible punishments (Singh, 2011). In addition, it contributes to the legitimation of the companies (Preuss, 2010).

The next step is to make the ethics norms explicit for each employee and stakeholder drawing particularly the attention of managers to their special responsibility since they play an enormous role in establishing ethical operation not only through their decisions, but by setting a good example (Watson \& Weaver, 2003). The most important point is that everyone has to take steps in accordance with the basic principles of ethics and the possibility must be given to discuss and report emerging ethical dilemmas and the possible ethical problems as well as taking such measures which prevent them in the future. Thus, all these can be encouraged by other ethics institutions (Kaptein \& Schwartz, 2008; Callaghan et al., 2012; Wheldon \& Webley, 2013), and real ethics programs beyond formal programs (MacLean et al., 2015).

The research of the code of ethics extends to more areas. One of them is surveying expansion. Furthermore, it is essential to examine the content of the code and to evaluate the effects of the code. In 1990, only $14 \%$ of the 200 largest companies in the world had code of ethics. In 2007, this rate was $86 \%$ (KPMG, 2008). According to the latest survey, this rate has decreased to $76 \%$. The reason for this decrease is that out of the 200 Asian companies of Fortune Global altogether, 42\% have their code of ethics (KPMG, 2014).

In spite of the criticism (e.g. Stonciuviene \& Naujokaitiene, 2013) according to empirical research, the content of the code was significant (Preuss, 2010; Erwin, 2011). Also, the really implemented code of ethics has a positive effect on the development of ethical company culture (Kaptein \& Schwartz, 2008), on the satisfaction of employees, and on the confidence towards the company (Wheldon \& Webley, 2013). It makes possible the encouragement of ethical development (Mercier \& Deslandes, 2016), and the establishment of a responsible and sustainable company (Bodolica \& Spraggon, 2013).

The characteristic of the transitional economies is that ethics institutionalization falls behind that of the developed countries. In Hungary, according to the survey by Ernst \& Young (2011) in the Hungarian corporate sector, $23 \%$ of the companies employing at least 50 people have their code of ethics. In addition, the majority (77\%) do not apply a code of ethics. The current research has examined the codes of ethics in the Hungarian TOP 200 
(Figyelö TOP 200, 2012) companies by a questionnaire survey. Furthermore, the research was preceded by company interviews (Szegedi, 2012a) and the content analysis of the codes of ethics (Szegedi, 2012b).

Lots of information can be realised on the fact whether a company has its code of ethics or not. If it has, what kind of code of ethics is that? What basic principles, stakeholders, and topics can be found in the code of ethics? How often is the code revised and what is the modification based on? However, those are the research questions we intended to find answers to during the survey. This is based on the questionnaire tested by the Hungarian Business Leaders Forum and the survey conducted by the Ethics and Transparency work team of the organization. Therefore, their subdivision was only for the purpose of the survey of the codes of ethics.

The rate of the returned questionnaire was $23.5 \%$. Based on the realised sample, $49 \%$ of the evaluated companies had 150000 million forints or more net income. $42 \%$ employ 2000 or more people, 51\% have 40000 million forints or more shareholder's equity, and $43 \%$ had 4000 million forints or more as profit after tax. In order to make the results of the research universal, only the answers of the companies having a code of ethics were taken into account. After that, we applied the method of post-stratification and reweighting. In addition, significant conclusions have been drawn concerning the TOP 200 companies having their own code of ethics.

When writing our current article, we do not have the goal of making a detailed special literature process. Rather, we will focus on the results of the realised empirical research. As such, the article contains, exclusively, the findings related to the code of ethics. Therefore, the part concerning the Hungarian reporting system has been summarized in another article (Szegedi \& Szilágyi, 2016).

\section{Empirical Research Results}

In the case of four fifths of the Hungarian companies having a code of ethics, they introduced their code of ethics 5 years ago or even earlier. Thus, in case of almost half of the companies (49\%), it was introduced 10 years ago or even earlier. Their own code of ethics or a similar document was introduced in case of $31 \%$ of the companies 5-9 years ago. Therefore, $10 \%$ of them were introduced 2-4 years ago, while $10 \%$ of them were introduced 1 or less than 1 year ago.

The majority of the companies (60\%) use the name code of ethics. In 23 percent of the companies, the phrase code or attitude/behaviour can be seen. However, in the following names such as company directive, basic principle can also be found. The length of the code ranges from 4 to 104 pages. On an average, it is 26 pages. It does not differ much from the 
American data since the codes of ethics of the largest American companies consist of 3-64 pages. Also, the average page is 28 pages (LeFebvre, 2011).

\section{The Aim of Introducing the Code}

In Hungary, the primary aim of introducing the code was to have a guidance to staff (80\%). In the second place, the aim of having a statement of ethical commitment could be found (57\%). On the other hand, the third one was to develop the company's culture (34\%). Figure 3 shows the aims of introducing the codes in Hungarian companies.

The results show great similarity to those in the research conducted by the Institute of Business Ethics in the circle of the FTSE 350 companies. Here, the primary aim was also to have a guidance to staff $(98 \%)$, the third aim was to create a shared and consistent company culture (85\%), and the fourth aim was to make a public statement of ethical commitment (83\%) (Webley et al., 2010; Wheldon \& Webley, 2013). In case of Fortune Global 200 a few years ago, the most essential driving force was to comply with legal requirements, 85\% of the companies marked this aim (KPMG, 2008). However, the survey conducted again in 2014 showed that the code was much rather intrinsically driven, namely: it was an important aspect to create a shared company culture as well as to improve the behaviour of employees (KPMG, 2014). The significant difference between the international and the Hungarian results is that for the international ones, the protection/improvement of the company's reputation was marked in the first or second place (KPMG, 2008; KPMG, 2014; Webley et al., 2010; Wheldon \& Webley, 2013). Also, the Hungarian companies do not consider this factor so important since only 7 percent of the companies have the aim of introducing the code. Through this way, it was only number seven in the list of priorities. In the above mentioned foreign surveys, $40 \%$ of the included global companies (KPMG, 2014), more than 30 percent of the European companies, and 63\% of the French companies (Webley et al., 2010) considered the introduction of the code to be important from the point of view of improving the company's competitive position. However, this rate is only $5 \%$ in the Hungarian survey. Similarly, the aspect of helping to reduce operational risk is important in the British, Spanish, and German companies (80-83\%) (Webley et al., 2010). All in all, 14 percent of the Hungarian companies marked it as an aim. There is a significant difference in the area of stakeholder expectations as well as in its perception. As a result, 74 percent of the largest global companies (KPMG, 2014) indicated meeting the stakeholder expectations as a very important driving force in the Hungarian survey. Altogether, 2 percent of the companies did that. Subsequently, a very small rate (4\%) of the Hungarian large companies found compliance with the legal requirements as the aim of introducing the code of ethics. 
In establishing the code of ethics in majority of the companies, the parent company (80\%), the top management (59\%), the HR organizational unit (55\%), the Legal organization (45\%), and the Compliance organizational unit (30\%) took part. Mostly, these units fulfilled the coordinating function as well. Several companies included representation of employees (27\%) and external expert/consultant (25\%) in the process.

About one fifth of the companies included the internal audit (23\%), the Communication organizational unit (20\%), and Sustainability (16\%). Fewer companies include the Security organizational unit (9\%), the Procurement (9\%), the Marketing (2\%), and Quality (2\%). Altogether, 16 percent of the companies involved employees, while only 7 percent involved external stakeholders in the establishment of the code.

Figure 1. The Aim of Introducing the Code

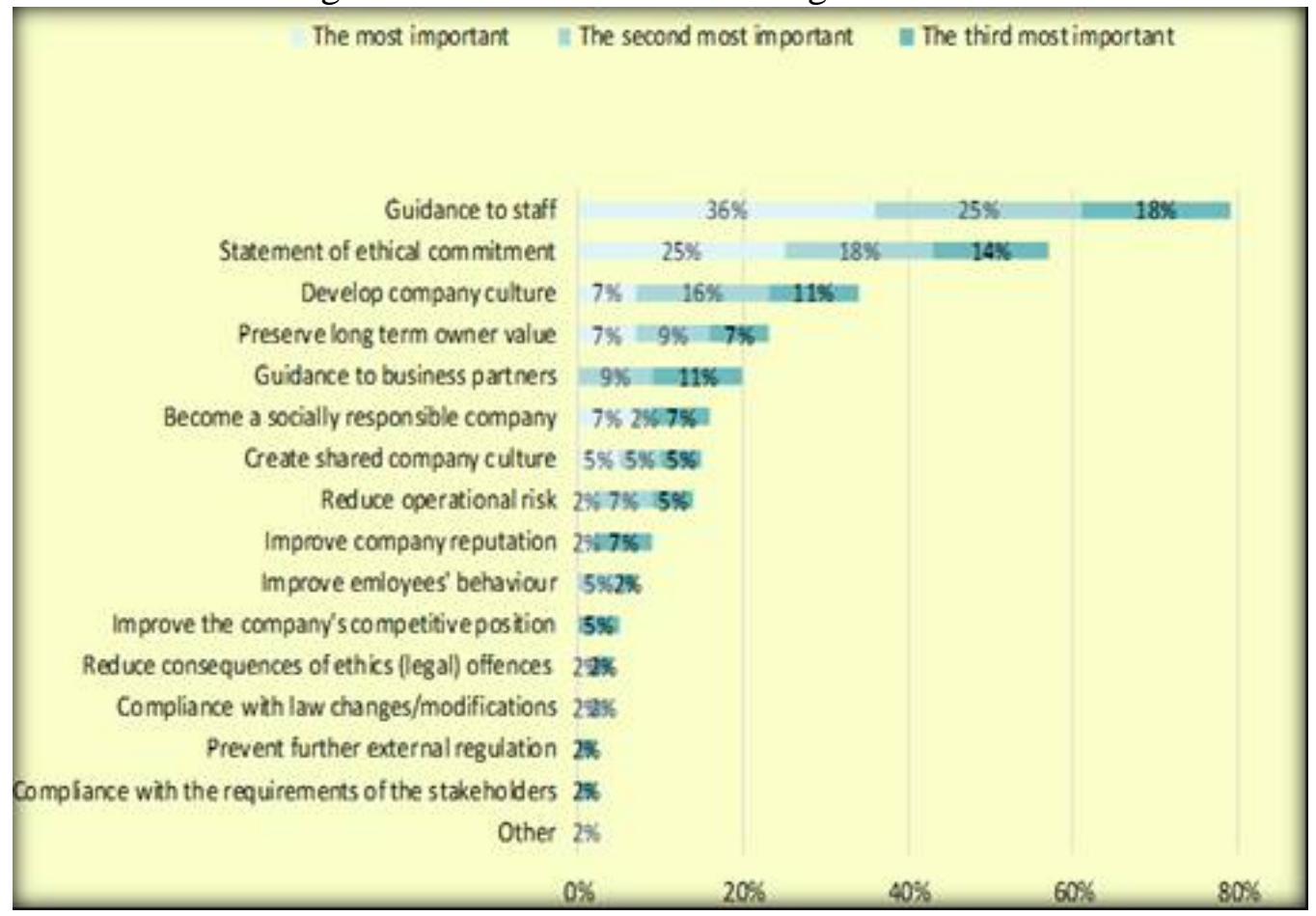

Source: Our data

\section{Values Appearing in the Codes of Ethics}

In Hungary, the majority (73\%) of the codes of ethics contain values/basic principles and rules as well. $18 \%$ contain only values/basic principles, while only 9\% are rule-oriented (Figure 4). Consequently, this rate is partly similar to the global results. This can be observed in the case of 73 percent of the largest global companies. Here, the code is a mix of general principles and detailed standards and rules. However, it is different in that in 22 percent of the global companies, the code is wholly rule-based; and in 
case of 5 percent of the global companies, the code is principle-based (KPMG, 2014). This rate is the opposite in the Hungarian codes. It is interesting that on the global level, the rate of the value as well as rule-based codes has decreased in the last few years, while the rate of the mixed codes has increased (KPMG, 2008; KPMG, 2014).

Figure 2. The Characteristics of the Codes of Ethics

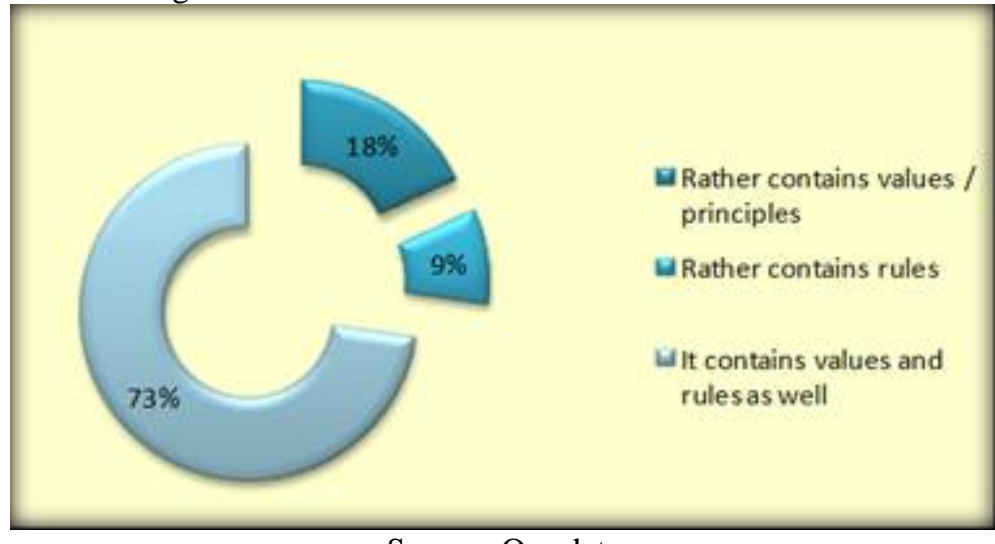

Source: Our data

Figure 5 shows the most important basic values that appear in the Hungarian codes of ethics. These values include integrity (93\%), honesty (91\%), responsibility (91\%), transparency (84\%), and respect (73\%). In a bit smaller rate, trust (66\%), cooperation (52\%), and justice (48\%) can be found.

Beyond the above listed basic values, in some of the codes, equal opportunity (9\%), reliability, fairness $(7 \%)$, compliance $(7 \%)$, customer orientation (7\%), diversity (7\%), integrity (5\%), and tolerance $(5 \%)$ can be found. Also, benignity, efficiency, competence, commitment, loyalty, appreciation, open communication, receptive work environment, keeping promises, and honest intentions were involved.

In the global survey integrity, 50\% appears most often. Respect (36\%) is in the second place. This is followed by honesty (34\%). In more than one fifth of the global companies, we can see responsibility (27\%), trust (26\%), customer orientation (22\%), and performance (20\%). 
Figure 3. Basic Values Appearing in the Codes of Ethics

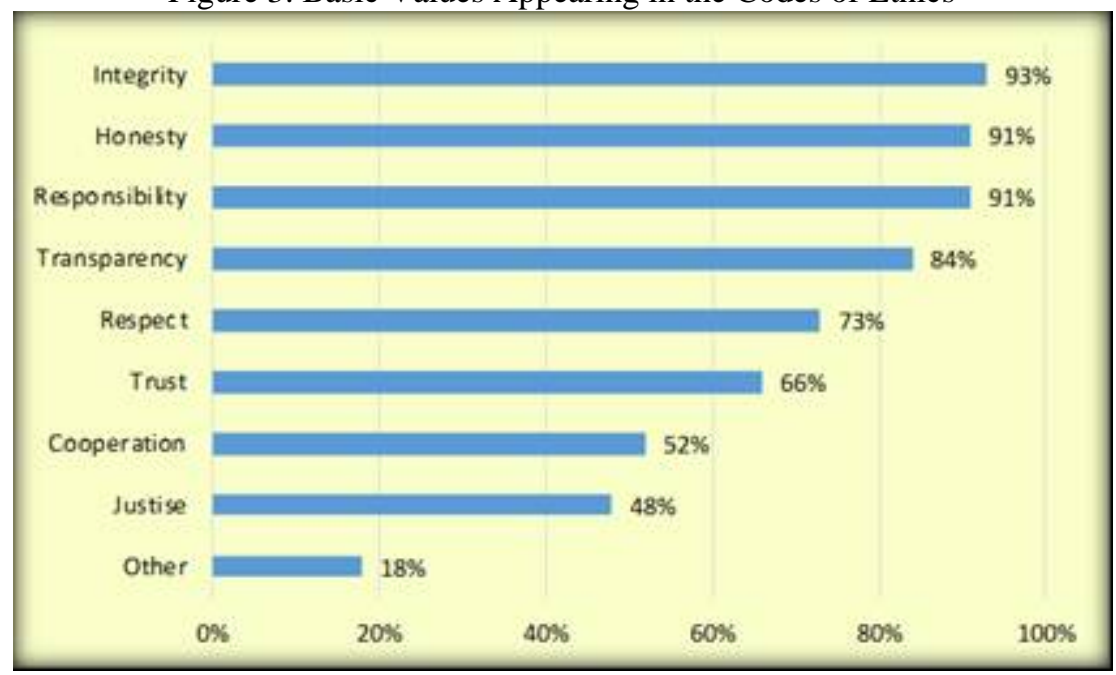

Source: Our data

There is also open communication (18\%), teamwork/cooperation (18\%), and innovation (15\%) (KPMG, 2014). The results show that in the Hungarian codes of ethics, the ethics values appear more often than in the international codes. In the last few years on the international level, the frequency of ethics values such as integrity, respect, responsibility, and trust has increased. On the other hand, the company's performance values, for instance, the frequency of being innovative, have decreased (KPMG, 2014; KPMG, 2008).

\section{Directives Appearing in the Code of Ethics}

Establishing the code of ethics can be encouraged by legal rules or by soft law directives. $43 \%$ of the established codes of ethics in Hungary refer to one or more external directives. The external directives which are the most frequently included in the codes are the UN Global Compact, The UN Declaration of Human Rights, and the ILO Core Conventions. The rate of occurrence is shown in Figure 6.

In the category called 'other', four companies named the law of Foreign Corrupt Practices Act (FCPA). Two companies named an industrial directive; one named the International Covenant on Economic, Social and Cultural Rights; and one more cites the laws concerning bonds trade. 
Figure 4. External Directives in the Hungarian Codes Ethics

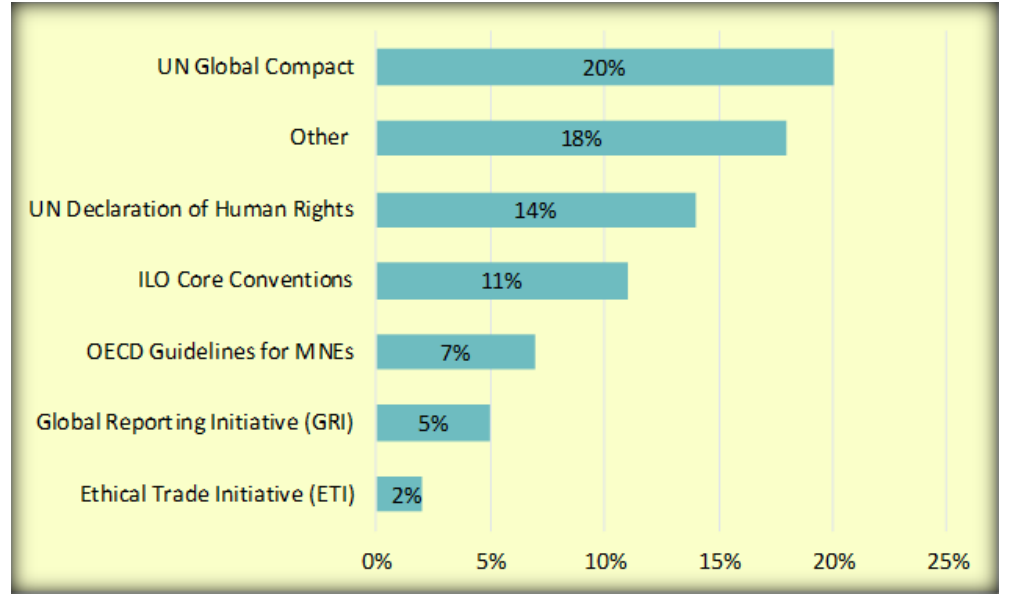

Source: Our data

\section{Stakeholders Appearing in the Codes}

In case of the Hungarian large companies, there are three emphasised stakeholders in the codes: their employees (95\%), their suppliers/business partners (93\%), and the management (91\%). In the codes of the majority, the owner/parent company (68\%), buyers (68\%), the state/government (66\%), the competitors (64\%), and the society (55\%) appeared. Less than half of the companies refer to the natural environment (45\%), the local community (36\%), employee representatives (36\%), and the civil organizations (34\%) in their code of ethics. Figure 7 shows the frequency of appearance of the stakeholders in the code of ethics.

When compared to the large global companies, we can state that in their codes of ethics, it is also the employees who occurs most frequently (95\%). In much more codes, the society (75\%) and the natural environment (70\%) can be found. The natural environment appears more often (73\%) and the business partners appear less frequently (37\%) (KPMG, 2014).

Figure 5. Stakeholders Appearing in the Code of Ethics

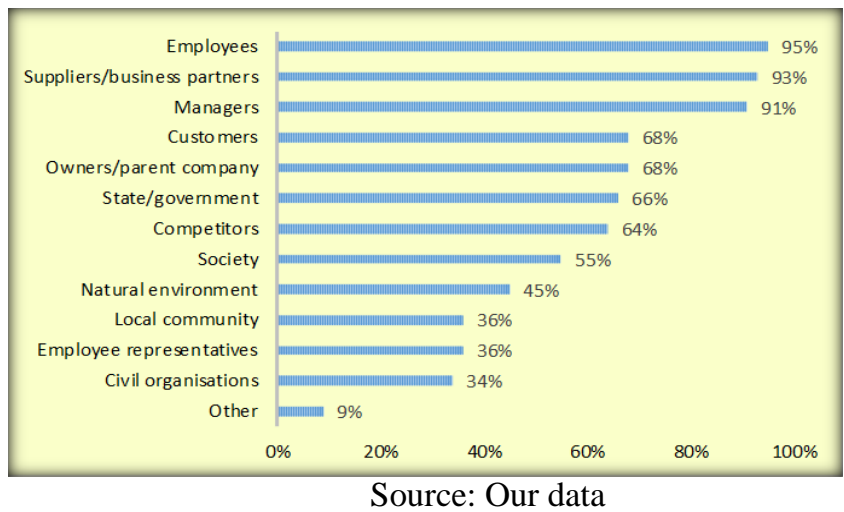




\section{Topics Included in the Codes of Ethics}

The most frequent topics of the Hungarian codes are bribery and corruption (95\%), gifts, entertainment (95\%), confidentiality (93\%), and conflict of interests (93\%). Concerning the codes of the largest global companies, confidentiality appears in 93 percent. Also, the topic corruption and bribery appears in 91 percent. Thus, it is followed by accuracy of reporting, fraud, and the protection of the organization's assets in 90 percent. Contrary to the Hungarian large companies, the topic of accepting gifts appeared in a smaller rate in 84 percent as well as conflict of interests in 83 percent (KPMG, 2014). The situation is the opposite in the case of the company's assets which can be found only in 73 percent of the Hungarian codes contrary to the international rate that is 90 percent. Hence, this refers to the socialist company past becoming a habit.

The topics of the Hungarian codes are shown in Figure 8. In more than 80 percent of them, we can find adherence to law (89\%), transparency and disclosure (86\%), applicability to all (84\%), refusing discrimination (82\%), and free and fair competition (82\%). In 70-73 percent of the codes, we can see the following topics, namely: use/misuse of company assets, special responsibility of the managers, obligation of reporting the breach of the code, workplace health and safety, harassment, accurate record keeping, insider trading, top management introduction, sanctioning the breach of the code, and whistle blower protection. In 60-68 percent of the codes, the possibility of anonymous reporting appears as well as environment protection, protection of personal data, political activities, not supporting political parties, and dealing with government officials. The least frequent topics are fundamental human rights (59\%), protection of intellectual rights (50\%), public representation (48\%), and safe products (45\%).

In the Hungarian codes compared to the international practice, the topics related to the protection of the company appears a little more frequently. Thus, this was defined by KPMG as staff responsibilities (KPMG, 2014). On the contrary, the specific responsibilities towards employees, such as workplace health and safety (70\%) and free from discrimination (82\%), are less common in the circle of the Hungarian companies. 
Figure 6. Topics Appearing in the Codes of Ethics

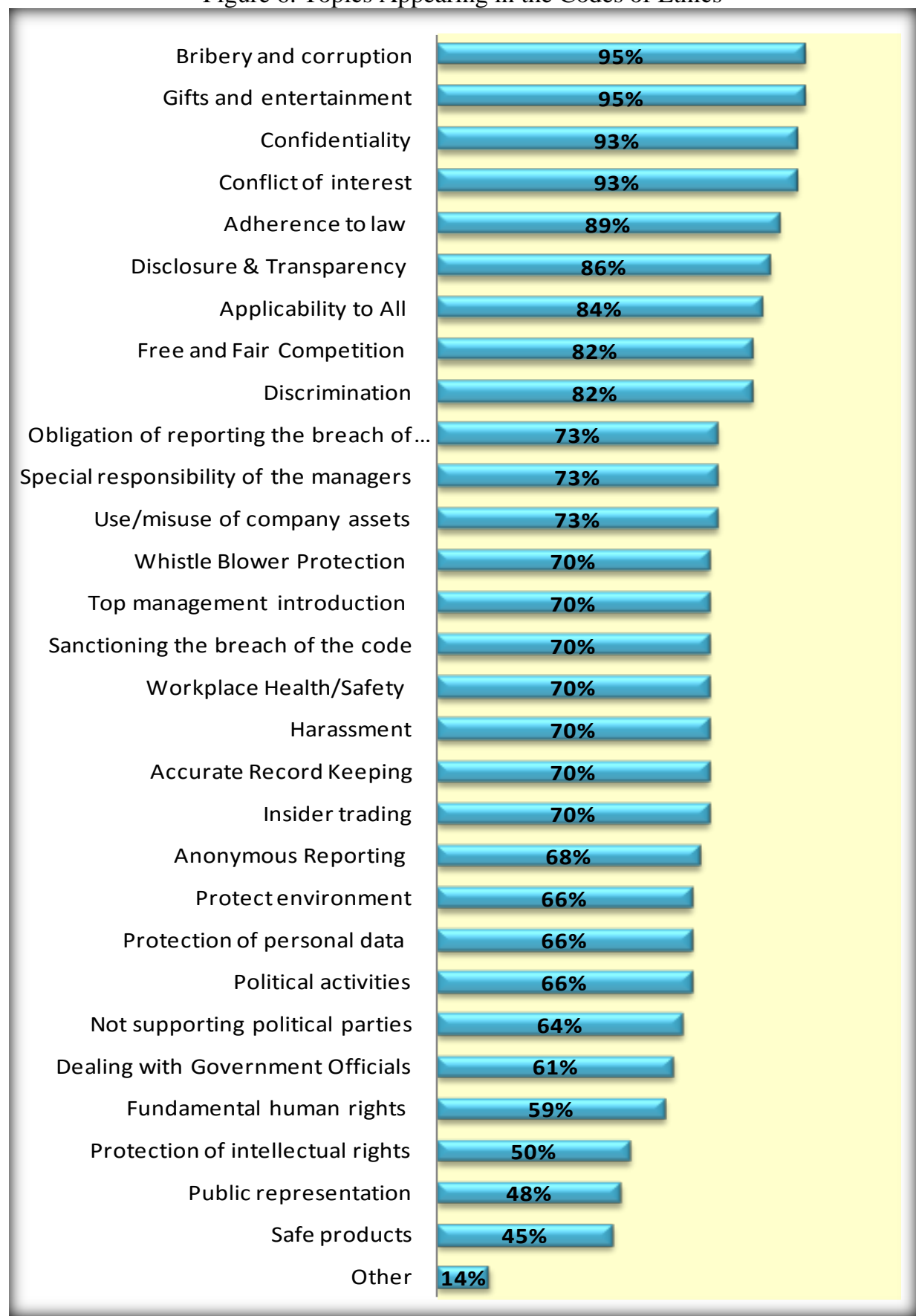

Source: Our data

The frequency of the same topics is $80 \%$ and $85 \%$ in the global companies (KPMG, 2014). The importance of the topics safety and security 
and environmental impact in the British survey directly follows the topic bribery, corruption, and facilitation payments.

\section{The Supplier's Codes of Ethics}

The code of ethics is part of the supplier/business partner contracts in 58 percent of the Hungarian companies. Therefore, this rate is slightly higher than the rate $46.4 \%$. This was stated in 2012 in the research of Transparency International (Alexa, 2012) which refers to a positive change. Furthermore, majority of the large companies made the code of ethics as part of the business partner contracts 2-4 years ago (Figure 9.).

Figure 7. The Code of Ethics as Part of the Supplier/Business Partner Contracts

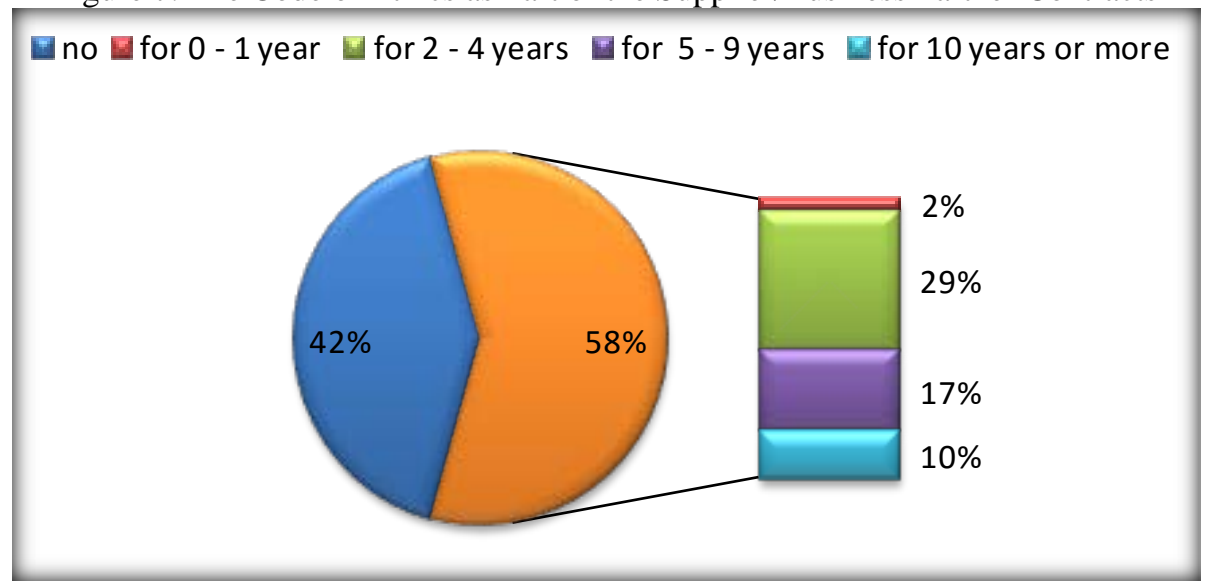

Source: Our data

Furthermore, 32 percent of the Hungarian large companies established a separate code of ethics related to the suppliers and business partners. The majority of the companies (50\%) with a separate supplier/business partner code introduced it 2-4 years ago. However, 34\% did that 5-9 years ago (Figure 10). The results show that before introducing the supplier/business partner code, the companies gained several years of experience (6-8 years) concerning the established code of ethics.

\section{The Revision of the Codes of Ethics}

The majority (53\%) of the Hungarian large companies plan to revise their codes of ethics if necessary. $9 \%$ revise theirs every two years, while $7 \%$ revise theirs every three years. Contrary to the Hungarian companies, nearly half (49\%) of the FTSE 350 companies revised their code every year. 24 percent did that within 2-4 years, $16 \%$ do that if necessary depending on the change of business or industry (Webley et al., 2010). However, it has shifted in the last few years and the majority (37\%) of the companies decided on revising if necessary (Wheldon \& Webley, 2013). 
Figure 8. The Frequency of the Supplier/Business Partner Codes of Ethics

$\square$ nincs $\square$-1 éve $\square$-4 éve $\square$-9 éve $\square 10$ éve, vagy régebben

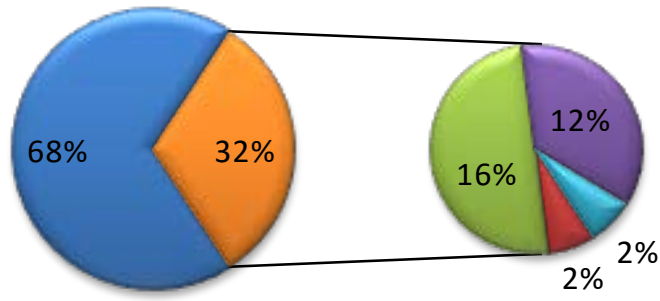

Source: Our data

When revising the code, most (84\%) of the companies consider the demand of the parent company/the owner as a significant part (68\%). This part takes the reflections of the top management and the changes of law into account (Figure 11). More than half (57\%) of the companies take employees' questionnaires/reflections and the changes of the business environment as a basis. Consultations with stakeholders were conducted by 48 percent of the companies. $45 \%$ take external standards/benchmark information into account, and only $32 \%$ consider the external advisor's opinion. In case of the FTSE 350 companies, the role of the external standards and benchmarking is much more significant (80\%) (Webley et al., 2010). Also, their importance has increased recently (Wheldon \& Webley, 2013). However, when it comes to revising the code, the primary aspect is the changing business environment/issues (Wheldon \& Webley, 2013).

Figure 9. Factors Considered When Revising the Code

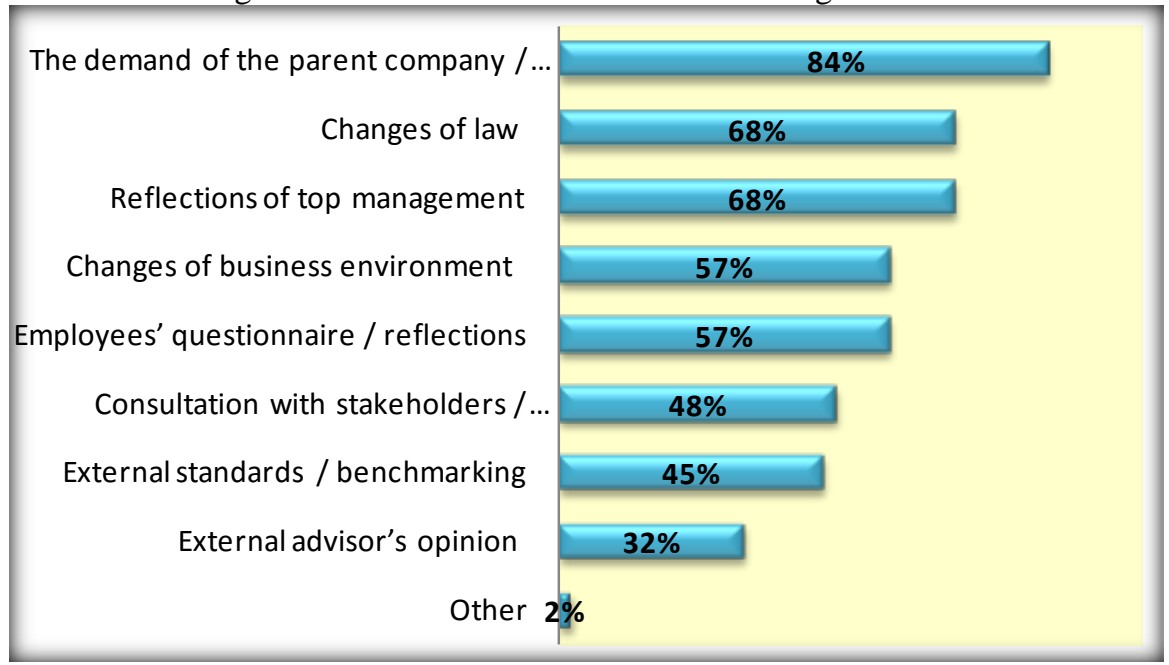

Source: Our data 


\section{Conclusion}

In the circle of the Hungarian large companies, the main aims of introducing the code of ethics are to make guidance to the staff, to declare ethical commitment, and to improve the company's culture. Consequently, improving competitiveness and the demand by stakeholders play insignificant roles.

In the Hungarian large companies, their code of ethics is primarily intended for their employees and a great part for their suppliers. However, taking responsibility in a wider scale voluntarily towards external stakeholders is less emphasised compared to the international practice. Due to the latter one, it is clear that, altogether, 7 percent of the companies involved external stakeholders in elaborating the code who the code is largely intended for. Thus, only 16 percent of the companies involved external stakeholders in developing the code. Based on this fact, we can draw the conclusion that in the practice of Hungarian large companies, the codes of ethics tend to be documents for regulations rather than documents for taking responsibilities. In Hungary, the ethical behaviour of companies is still not encouraged by either law or by the market participants. Also, it is not expected by the company stakeholders in a wider sense.

In the Hungarian codes of ethics, great emphasis is laid on the protection of company interests in spite of the individual's personal benefit. The most common topics of the Hungarian codes are bribery and corruption, gifts, entertainment, confidentiality, and conflict of interests. The special responsibility taken for the employees, for instance workplace health and safety, freedom from discrimination and harassment, occurs less frequently.

The practice of the code of the Hungarian large companies contradicts the global tendency. This states that the codes are more and more comprehensive with more goals, defines corporate responsibility, and are not only focused on the do's and don'ts of the employees (KPMG, 2014). Consequently, we can note that there are positive changes concerning the extension of the ethics values related to the supply chain. However, it is still only 58 percent of the companies which make up the code of ethics as part of the supplier/business partner contracts. In the case of approximately half of the Hungarian large companies, we can say that the revision of the codes of ethics is not conducted on a regular basis which prevents it from becoming a living document. The results of the research show that there is still room for improvement in the codes of ethics of the Hungarian companies.

\section{References:}

Alexa (2012). Figyelő Top 200. Üzleti etika és korrupció. Transparency International kutatás. 
Bodolica \& Spraggon (2015). An Examination into the Disclosure, Structure, and Contents of Ethical Codes in Publicly Listed Acquiring Firms. Journal of Business Ethics (2015) 126:459-472

Brenner (1992). Ethics programs and their dimensions. Journal of Business Ethics 1992; 11(5-6):391-9

Callaghan et al. (2012). Code of ethics quality: An international comparison of corporate staff support and regulation in Australia, Canada and the United States. Business Ethics: A European Review, 21(1),15-30.

Ernst \& Young (2011). Integritás és korrupciós kockázatok a magyar vállalati szektorban

2010.http://www.ey.com/Publication/vwLUAssets/Korrupci\%C3\%B3s_Koc k\%C3\%A1zatok_2011/\$File/Integrit\%C3\%A1s_Korrupci\%C3\%B3s_kock\% C3\%A1zatok_11022011.pdf Downloaded 2011. February 27.

Erwin (2011). Corporate codes of conduct: The effects of code content and quality on ethical performance. Journal of Business Ethics, 99, 535-548.

Figyelö TOP 200 (2012).

Garegnani et al. (2015). Scoring Firms' Codes of Ethics: An Explorative Study of Quality Drivers. Journal of Business Ethics (2015) 126:541-557.

Kaptein \& Schwartz (2008). The Effectiveness of Business Codes: A Critical Examination of Existing Studies and the Development of an Integrated Research Model. Journal of Business Ethics 77, 111-127.

Kaptein (2009). Ethics Programs and Ethical Culture: A Next Step in Unraveling Their Multi-faceted Relationship. Journal of Business Ethics (2009) 89:261-281.

Koonmee et al. (2010). Ethics institutionalization, quality of work life, and employee job-related outcomes: A survey of human resource managers in Thailand. Journal of Business Research 63 (2010) 20-26.

KPMG (2008). Business Code of the Global 200: Their Prevalence, Content and Embedding (KPMG, Amsterdam). http://www.kpmg.com/CN/en/IssuesAndInsights/ArticlesPublications/Docu ments/business-codes-global-200-O-0804.pdf Downloaded 2011 January 15. KPMG (2014). The Business Codes of the Fortune Global 200. What the largest companies in the world say and do.

LeFebvre (2011). Cross-Cultural Comparison of Business Ethics in the U.S. and India: A Study of Business Codes of Conduct. Journal of Emerging Knowledge on Emerging Markets, Volume 3. November 2011.

MacLean et al. (2015). When Organizations Don’t Walk Their Talk: A Cross-Level Examination of How Decoupling Formal Ethics Programs Affects Organizational Members. Journal of Business Ethics (2015) 128:351-368. 
Mercier \& Deslandes (2016). There are no Codes, Only Interpretations. Practical Wisdom and Hermeneutics in Monastic Organizations. Journal of Business Ethics, February 2016.

Oladinrin \& Ho (2015). Integrating codes of ethics in Hong Kong construction organizations-practitioners' perspective. Asian Journal of Business Ethics (2015) 4:15-33.

Preuss (2010). Codes of conduct in organizational context: From cascade to lattice-work of codes. Journal of Business Ethics, 94(4), 471-487

Singh (2011). Determinants of the effectiveness of corporate codes of ethics: An empirical study. Journal of Business Ethics, 101, 385-395

Stonciuviene \& Naujokaitiene (2013). Formation of The Ethics of Professional Accountants from a Moral Standpoint: Analysis of Decisive Factors and Their Influence. European Scientific Journal December 2013 /SPECIAL/ edition Vol.1

http://eujournal.org/index.php/esj/article/view/2275 Downloaded 2016 May 17.

Szegedi \& Szilágyi (2016). Ethics And Compliance Whistleblowing Systems In Hungarian Large Companies. European Scientific Journal March 2016 edition vol.12, No.7 ISSN: 1857 - 7881 (Print) e - ISSN 1857- 7431.

Szegedi (2012a). A magyar nagyvállalatok etikai intézményei. Mühelytanulmány, TÁMOP-4.2.1.B-09/1/KMR-2010-0005 azonosítójú project, „Fenntartható fejlődés”. pp. 1-76.

Szegedi (2012b). Hazai nagyvállalati kódexek tartalmi elemzése. Vezetéstudomány, Különszám, 2012. szeptember

Valentine \& Fleischman (2008). Ethics programs, perceived corporate social responsibility and job satisfaction. Journal of Business Ethics 2008; 77:15972.

Watson \& Weaver (2003). How internationalization affects corporate ethics: formal structures and informal management behaviour. Journal of International Management 9 (2003) 75-93.

Wheldon \& Webley (2013). Corporate ethics policies and programmes: UK and Continental European survey. London: Institute of Business Ethics.http://www.ibe.org.uk/userfiles/codes_survey_2013_interactive.pdf Downloaded 2016 May 2. 